\title{
Pengaruh Perhatian Orang Tua terhadap Prestasi Belajar Mata Pelajaran Pendidikan Agama Islam Siswa Sekolah Dasar
}

Fidia Rahmawati ${ }^{1}$, Wirdati ${ }^{2}$

rahmawatifidia123@gmail.com 1, wirdati@fis.unp.ac.id ${ }^{2}$ Universitas Negeri Padang ${ }^{1,2}$

\begin{tabular}{l}
\hline ARTICLE INFO \\
\hline Article history: \\
Received, 24 September \\
2021 \\
Revised, 09 November \\
2021 \\
Accepted, 30 November \\
2021 \\
\hline Keywords: \\
Perhatian Orang Tua, \\
Prestasi Belajar, \\
Pendidikan Agama Islam \\
\hline Clonflict of Interest: \\
None \\
\hline
\end{tabular}

\section{Funding:}

None

\begin{abstract}
Penelitian ini bertujuan untuk mendeskripsikan perhatian orang tua terhadap siswa, prestasi belajar mata pelajaran Pendidikan Agama Islam siswa, dan pengaruh perhatian orang tua terhadap prestasi belajar mata pelajaran Pendidikan Agama Islam siswa di SD Negeri 161/II Bukit Sari. Penelitian ini adalah penelitian kuantitatif asosiatif dengan teknik penganalisisan data deskriptif kuantitatif, uji prasyarat analisis menggunakan uji normalitas dan linearitas untuk uji hipotesis dilakukan analisis regresi linier sederhana. Pengambilan sampel dilakukan dengan teknik purposive sampling. Hasil penelitian ini menunjukkan bahwa perhatian orang tua siswa dalam kategori tinggi. Sedangkan prestasi belajar siswa SD Negeri 161/II Bukit Sari Kabupaten Bungo tergolong dalam kategori sedang. Hasil perhitungan dari analisis Uji $\mathrm{T}$ diperoleh $t_{\text {hitung }}>\mathrm{t}_{\text {tabel }}(2,309>1,682)$ menunjukkan $\mathrm{H}_{\mathrm{o}}$ ditolak dan $\mathrm{H}_{\mathrm{a}}$ diterima. Dan hasil perhitungan dari analisis regresi linier sederhana diperoleh nilai $\mathrm{F}_{\text {hitung }}=5,330$ dan $\mathrm{F}_{\text {tabel }}=4,067$ dengan nilai signifikansi $0,026<0,05$. Jadi $F_{\text {hitung }}>F_{\text {tabel }}(5,330>4,067)$ sehingga dapat diartikan bahwa $\mathrm{H}_{0}$ ditolak. Artinya terdapat pengaruh yang signifikan antara perhatian orang tua terhadap prestasi belajar siswa. Dengan demikian diharapkan orang tua dapat memberikan perhatian dan bimbingan belajar serta suri tauladan yang baik bagi anak, meskipun perhatian orang tua sudah baik namun orang tua juga harus mempertahankan bentuk perhatiannya seperti memenuhi kebutuhan belajar, memberi pengawasan saat belajar, memberi reward dan hukuman serta menciptakan suasana belajar yang nyaman sehingga anak bisa mendapatkan prestasi belajar sesuai dengan yang diharapkan.
\end{abstract}

Corresponding Author: Fidia Rahmawati, Department Islamic Education Faculty of Social Science Universitas Negeri Padang, Indonesia, Email: rahmawatifidia123@gmail.com Phone: +62853-55616462 
prestasi yang diperoleh siswa. Faktor yang mempengaruhi meliputi faktor internal dan eksternal. Faktor internal adalah faktor yang berasal dari dalam diri individu, seperti faktor fisiologis dan psikologis, sedangkan faktor eksternal adalah faktor yang berasal dari luar individu, seperti lingkungan sosial keluarga, lingkungan sosial sekolah, dan lingkungan sosial masyarakat (Wahab, 2016).

Lingkungan sekolah memiliki pengaruh yang besar terhadap hasil belajar, terutama jika menyangkut lingkungan siswa (Latief, 2014). Tentu saja, jika siswa dapat memilih teman yang benar, tidak akan ada masalah. Namun, banyak siswa terkadang terjebak dalam berteman yang buruk, yang dapat menyebabkan penurunan nilai. Contohnya berteman dengan orang yang malas belajar, suka main game, dan sebagainya. Hal-hal seperti ini hanya akan membuat siswa lupa akan pentingnya belajar. Sebagai orang yang paling dekat dengan siswa, kontrol orang tua diperlukan untuk menghindari hal seperti itu. Orang tua harus selalu memperhatikan anak-anaknya, memantau perkembangannya di sekolah, dan memperhatikan siapa saja teman anaknya dan apakah membawa dampak positif atau negatif.

Lingkungan sosial yang kondusif akan mempengaruhi kegiatan belajar dan berdampak menguntungkan bagi prestasi siswa (Sandrawati, 2016). Sebaliknya, jika lingkungan sosial siswa buruk, maka akan berdampak negatif pada prestasi belajar siswa. Hal ini karena lingkungan sosial di sekitar siswa memiliki pengaruh yang besar dalam perkembangan kepribadian mereka.

Dari semua faktor eksternal, orang tua berperan penting dalam menentukan prestasi belajar. Orang tua adalah pendidik pertama dan utama bagi anak-anaknya. Orang tua tetap berperan dalam keberhasilan belajar anaknya, meskipun sudah dititipkan ke sekolah (Umar, 2015). Orang tua termasuk dalam lingkungan keluarga, khususnya perhatian orang tua. Dalam kegiatan belajar, anak sangat membutuhkan perhatian orang tua. Dalam lingkungan keluarga, perhatian orang tua dalam belajar anak memiliki pengaruh terhadap prestasi belajar anak di lingkungan rumah (Slameto, 2010).

Keluarga merupakan faktor paling penting yang mempengaruhi kehidupan anak di rumah, sekolah, dan masyarakat (Ristianah, 2015). Keluarga yang tinggal di dekat anak tentu berperan sebagai sarana pendidikan utama untuk mengenali lingkungannya. Sementara itu (Lie et al., 2014) orang tua dapat meningkatkan sekaligus menghambat tumbuh kembang anaknya.

Perhatian orang tua merupakan lingkungan utama dan paling dekat dengan anak yang menjadi hal penting. Anak-anak membutuhkan perhatian dan bantuan orang tua untuk mengarahkan kehidupan dan mencapai prestasi belajar mereka. Perhatian orang tua juga penting untuk kemajuan belajar anak (Qomariyah, 2015).

Berdasarkan observasi awal di SD Negeri 161/II Bukit Sari Kabupaten Bungo ditemukan siswa yang belum menyelesaikan tugas atau pekerjaan rumah yang diberikan oleh guru, siswa malas saat proses belajar, siswa sulit berkonsentrasi ketika belajar, siswa sibuk mengganggu teman sebangkunya, siswa mengacuhkan prestasi belajar yang diraihnya, tingkah laku siswa yang kurang sopan, dari hal tersebut akan berpengaruh pada hasil belajar sehingga menyebabkan prestasi anak menjadi menurun. Berdasarkan hal tersebut terlihat bahwa ada sebagian siswa yang belum memenuhi kriteria kelulusan minimal (KKM). Adapun prestasi belajar yang dicapai siswa bervariasi, beberapa siswa mencapai tingkat prestasi yang tinggi dan adapula yang rendah. Perbedaaan prestasi tersebut salah satunya dipengaruhi oleh faktor dari luar diri individu yaitu perhatian yang diberikan orang tua.

Orang tua yang senantiasa mengawasi dan mendampingi anaknya selama belajar, misalnya orang tua yang senantiasa mengarahkan dan memberikan bimbingan belajar kepada anaknya, akan mendorong anaknya menjadi giat belajar. Bentuk perhatian yang ditunjukkan saat anak di rumah merupakan salah satu faktor yang akan berpengaruh terhadap prestasi belajar anak di sekolah. Sekolah berupaya semaksimal mungkin untuk mengkomunikasikan hasil belajar setiap siswa kepada orang tuanya. Perhatian orang tua dianggap penting karena merupakan salah satu faktor yang mempengaruhi keberhasilan atau prestasi seorang siswa (Zindiari, 2020). 
Fidia Rahmawati dan Wirdati: Pengaruh Perhatian Orang Tua terhadap Prestasi Belajar...

\section{Tinjauan Pustaka}

Pendidikan agama Islam merupakan upaya untuk membantu peserta didik agar dapat mengamalkan ajaran agamanya, dengan pembinaan kepribadian anak, khususnya penanaman akhlak yang baik agar peserta didik memiliki kepribadian yang baik, menjadi aspek terpenting dari pendidikan agama (Djaelani, 2013). Pendidikan agama Islam juga berarti upaya membimbing peserta didik agar setelah menyelesaikan pendidikannya dapat memahami apa yang terkandung dalam Islam, menghayati makna dan tujuan Islam, mengamalkannya, dan menjadikan ajaran Islam sebagai pandangan hidup sehingga mereka dapat membawa keselamatan di dunia ini dan di akhirat (Daradjat, 2011). Dapat disimpulkan bahwa pendidikan agama Islam merupakan proses pembentukan sikap, kepribadian, serta gaya hidup. Pendidikan agama bertujuan memberikan bimbingan dan arahan tentang pendidikan agama Islam kepada peserta didik membentuk karakter dan budi pekerti anak agar mengamalkan ajaran Islam dan menjadikannya pedoman hidup. Dalam tingkat SD, SMP dan SMA pendidikan agama Islam adalah salah satu mata pelajaran wajib di sekolah yang bertujuan untuk membekali siswa dengan nilai-nilai ajaran Islam sehingga anak memiliki karakter yang islami. Di samping itu dalam mengevaluasi keberhasilan proses pembelajaran pendidikan agama Islam dapat dilihat melalui prestasi belajar yang diperoleh siswa.

Prestasi belajar adalah tingkat keberhasilan yang diperoleh dari suatu kegiatan atau usaha yang dapat memberikan kepuasan emosional, dan dapat diukur dengan menggunakan berbagai alat atau tes penilaian tertentu (Wahab, 2016). Kemampuan seorang peserta didik untuk menerima pengetahuan dari kegiatan belajar mengajar disebut sebagai prestasi belajar (Hamdu \& Agustina, 2011). Jadi, prestasi belajar adalah kemampuan atau hasil seseorang setelah menyelesaikan proses belajar sesuai dengan kemampuan yang dimilikinya.

Menurut (Syah, 2013), pengembangan hasil belajar yang optimal pada prinsipnya meliputi semua ranah psikologis yang berubah sebagai akibat dari pengalaman dan proses belajar siswa. Dengan demikian, prestasi belajar dapat dibagi menjadi tiga macam: a) Prestasi yang bersifat kognitif ialah pengamatan, ingatan, pemahaman, penerapan atau aplikasi, analisis (pemeriksaan dan penilaian yang cermat), dan sintesis (membuat kombinasi baru dan utuh). b) Prestasi yang bersifat afektif adalah penerimaan, penyambutan, penghargaan (apresiasi), dan internalisasi. c) Prestasi yang bersifat psikomotor adalah keterampilan gerak dan tindakan, serta keterampilan ekspresi verbal dan nonverbal.

Berikut beberapa faktor yang mempengaruhi prestasi belajar (Syah, 2012): a. Faktor internal adalah yang berasal dari dalam diri siswa: 1) Aspek fisiologi yaitu semangat dan intensitas siswa dalam mengikuti pelajaran dapat dipengaruhi oleh kondisi fisik yang sehat, segar, dan kuat. 2) Aspek psikologis antara lain: inteligensi siswa, sikap siswa, bakat siswa, minat siswa, motivasi siswa. b. Faktor eksternal siswa adalah faktor yang berasal dari luar diri siswa. Ada dua jenis faktor eksternal: 1) Faktor lingkungan sosial antara lain lingkungan keluarga, lingkungan sekolah, dan lingkungan masyarakat semuanya merupakan bagian dari lingkungan sosial. 2) Faktor lingkungan non-sosial adalah bangunan sekolah dan letaknya, letak rumah keluarga siswa, alat dan sumber belajar, kondisi cuaca, dan waktu belajar siswa, semuanya merupakan bagian dari lingkungan nonsosial. Salah satu faktor dari luar diri siswa yang dibahas dalam penelitian ini adalah lingkungan keluarga yaitu perhatian orang tua.

Perhatian orang tua adalah suatu tindakan yang dilakukan oleh orang tua yang tertuju pada aktivitas anaknya ketika sedang belajar (Mawarsih et al., 2013). Perhatian orang tua dapat berarti pemusatan energi psikologis yang diarahkan pada suatu objek yang dilakukan ayah dan ibu kepada anaknya ketika melakukan suatu aktivitas (Nisa, 2015). Jadi, perhatian orang tua dapat disimpulkan sebagai pemusatan semua aktifitas yang dilakukan oleh orang tua dan keluarga dengan penuh kasih sayang dan tanggung jawab untuk anak-anak.

Adapun bermacam-macam bentuk perhatian orang tua adalah: a) Atas dasar intensitasnya, yaitu banyak sedikitnya kesadaran menyertai suatu aktivitas atau pengalaman batin, dibedakan menjadi perhatian intensif dan perhatian tidak intensif. b) Perhatian berdasarkan cara timbulnya yaitu perhatian spontan dan perhatian sekehendak. c) Perhatian berdasarkan luas objek yaitu perhatian terpencar dan perhatian terpusat. Faktor-faktor yang 
mempengaruhi perhatian orang tua(Ahmadi, 2009) yaitu pembawaan, latihan dan kebiasaan, kebutuhan, kewajiban, keadaan jasmani, suasana jiwa, dan suasana di sekitar.

Beberapa indikator perhatian orang tua (Slameto, 2010): a) Pemberian bimbingan belajar, orang tua merupakan pendidik utama sekaligus teladan anak-anak mereka. Anakanak akan meniru semua yang dilakukan orang tua mereka tanpa mereka sadari. Oleh sebab itu orang tua hendaknya memberikan bimbingan belajar kepada anak dengan sebaik-baiknya. b) Pengawasan terhadap belajar, pengawasan orang tua dimaksudkan untuk menumbuhkan kedisiplinan agar pendidikan anak tidak terabaikan, karena terabaikannya pendidikan anak akan merugikan dirinya dan lingkungannya jika diabaikan. c) Pemberian penghargaan dan hukuman, orang tua hendaknya memuji dan menghargai atas prestasi anak-anak mereka. Hadiah dimaksudkan untuk menginspirasi anak-anak, membuat mereka gembira, dan mempererat hubungan antara orang tua dan anak-anak mereka. Hukuman dimaksudkan untuk mencegah perilaku buruk sekaligus mengajari anak-anak bagaimana menghentikan perilaku buruk tersebut. Hukuman tidak boleh berlebihan, apalagi sampai membuat anak trauma. d) Pemenuhan kebutuhan belajar, tersedianya fasilitas dan kebutuhan belajar yang memadai akan berdampak positif terhadap belajar anak. Anak-anak dengan fasilitas belajar yang kurang memadai seringkali tidak memiliki semangat untuk belajar. Di sisi lain, anak akan semangat jika semua kebutuhan mereka terpenuhi. Oleh karena itu, sudah sepatutnya orang tua memperhatikan kebutuhan belajar anak-anaknya dan memenuhinya. e) Menciptakan suasana belajar yang tenang dan tentram, orang tua sebaiknya menciptakan lingkungan rumah yang aman dan nyaman bagi anak-anaknya untuk belajar. Jika suasana di rumah tenang dan tenteram, anak akan merasa nyaman dan dapat fokus saat belajar. Sebaliknya, lingkungan rumah yang ramai dan tidak bersahabat akan membuat anak sulit untuk berkonsentrasi saat belajar. f) Memperhatikan kesehatan anak orang tua harus memperhatikan makanan yang dimakan anaknya, nutrisi dari makanan yang diberikannya, tidurnya, dan kesehatannya secara keseluruhan. Ketika anak sakit, orang tua harus membawanya ke bidan atau puskesmas terdekat. Ketika kesehatan anak-anak baik, kegiatan belajar mereka berjalan dengan lancar, memungkinkan mereka mendapatkan prestasi belajar yang maksimal.

Sehubungan dengan hal tersebut menunjukkan bahwa cara orang tua mendidik anakanak memberikan pengaruh pada pembelajaran mereka. Orang tua yang tidak peduli terhadap pendidikan anaknya, seperti tidak memperhatikan belajar anaknya, tidak memperhatikan kepentingan dan kebutuhan belajar anaknya, tidak mengatur waktu belajar anaknya, tidak menyediakan dan melengkapi alat belajar anaknya dan lain-lain, tidak memperhatikan apakah anak sedang belajar atau tidak, tidak ingin mengetahui bagaimana perkembangan anak dalam belajarnya, dan tidak ingin mengetahui kesulitan belajar yang dihadapi anak. Akibatnya prestasi akademik anak bisa menurun (Pratiwi, 2015).

Perhatian orang tua memiliki pengaruh terhadap keberhasilan prestasi anak. Karena jika orang tua memperhatikan anaknya, maka anak akan belajar lebih giat dan memiliki sifat yang lebih baik saat berada di rumah, di sekolah, dan di masyarakat. Sehingga dapat dikatakan bahwa perhatian orang tua berpengaruh positif terhadap prestasi belajar siswa.

\section{Metode}

Jenis penelitian yang penulis gunakan adalah penelitian kuantitatif dengan teknik penganalisisan data deskriptif, asosiatif dan analisis regresi linier sederhana. Populasi penelitian ini adalah siswa siswi SD Negeri 161/II Bukit Sari Kabupaten Bungo yang berjumlah 131 siswa dan sampel yang di peroleh yaitu sebanyak 44 siswa. Sampel yang diambil adalah kelas IV dan kelas V SD 161/II Bukit Sari Kabupaten Bungo yang terdaftar pada tahun pelajaran 2020/2021. Subyek penelitian dalam penelitian ini adalah siswa-siswi yang melakukan pembelajaran Pendidikan Agama Islam di SD Negeri 161/II Bukit Sari. Informan penelitian dalam penelitian ini adalah guru mata pelajaran Pendidikan Agama Islam dan siswa-siswi SD Negeri 161/II Bukit Sari. 
Fidia Rahmawati dan Wirdati: Pengaruh Perhatian Orang Tua terhadap Prestasi Belajar...

\section{Hasil dan Pembahasan}

\section{A. Perhatian Orang Tua Siswa SD Negeri 161/II Bukit Sari Kabupaten Bungo}

Perhatian orang tua merupakan salah satu faktor yang berperan penting bagi kehidupan anak. Perhatian merupakan pemusatan tenaga psikis yang tertuju pada suatu objek, atau banyak sedikitnya kesadaran yang menyertai suatu aktifitas yang dilakukan (Suryabrata, 2013). Menurut (Darajat, 2010) orang tua adalah pembina pertama dalam hidup anak. Kepribadian orang tua, sikap dan cara hidup mereka merupakan unsur-unsur pendidikan yang secara tidak langsung dengan sendirinya akan masuk ke dalam pribadi anak. Sejalan dengan hal tersebut (Darajat, 2010) Perhatian orang tua yaitu pemusatan energi yang dilakukan secara sengaja dan intensif dari orang tua dilandasi rasa penuh kasih sayang dalam melakukan tindakan demi prestasi belajar anak (Ningsih \& Nurrahmah, 2016).

Karena pendidikan keluarga merupakan pondasi pertama dan terpenting, maka tidak heran jika Islam sangat menjunjung tinggi pendidikan keluarga.

Sebagaimana firman Allah SWT yang berbunyi:

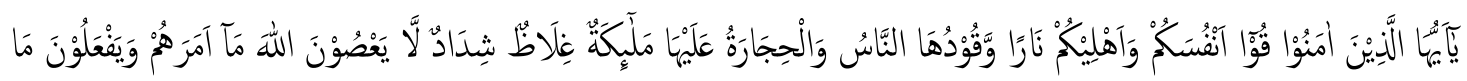

Artinya:

"Wahai orang-orang yang beriman, peliharalah diri dan keluargamu dari api neraka"

(QS. At-Tahrim: 6)

Penjelasan ayat di atas, orang tua berkewajiban memberikan pendidikan kepada anak-anaknya. Oleh karena itu, orang tua bertanggung jawab penuh atas pendidikan anakanaknya. Dia tidak bisa begitu saja melepaskan beban ini kepada orang lain dengan menyerahkan kepada sekolah. Meskipun sekolah hanya menerima tugas dari orang tua, orang tua tetap memiliki tanggung jawab yang besar terhadap pendidikan anak-anaknya.

Perhatian orang tua merupakan kesadaran jiwa orang tua untuk mempedulikan anaknya, terutama dalam hal memberikan pendidikan, bimbingan dan memenuhi kebutuhan anaknya, baik dalam segi emosional maupun material. Setiap orang tua pasti menginginkan anaknya pandai dan berakhlak mulia (Hasibuan, 2019). Untuk mencapai keberhasilan anak seperti yang diinginkan orang tua, perlu disadari bahwa orang tua sangat penting pengaruhnya. Setiap anak yang menjalani proses pendidikan memerlukan peran dan dukungan dari orang tua. Seperti cara orang tua dalam memenuhi kebutuhan psikologis anak dengan memberi perhatian, ketersediaan fasilitas belajar di rumah, suasana rumah, serta kesehatan anak. Terlebih lagi jika orang tua selalu mengawasi dan mendampingi anak dalam belajar, misalnya orang tua yang selalu mengarahkan, memberi bimbingan belajar kepada anak akan membuat anak menjadi rajin belajar. Partisipasi orang tua dalam bentuk perhatian yang diberikan saat anak di rumah merupakan salah satu faktor yang akan berpengaruh terhadap prestasi belajar siswa di sekolah. Sejalan dengan hal tersebut Slameto (2010) memaparkan bahwa ada beberapa indikator perhatian orang tua yaitu orang tua memberikan bimbingan belajar kepada anak, memberikan pengawasan belajar, memberikan penghargaan dan hukuman, memenuhi kebutuhan belajar, menciptakan suasana belajar yang tenang dan tentram dan memperhatikan kesehatan anak.

Perhatian orang tua merupakan salah satu faktor eksternal yang mempunyai peranan penting, keluarga sangat menentukan berhasil tidaknya anak yang berhubungan dengan keberhasilan prestasi belajar dalam proses pembelajaran. Jika tidak ada perhatian dari orang tua maka tujuan yang ingin dicapai tidak dapat berjalan dengan lancar. Dalam penelitian ini, peneliti ingin mengetahui bagaimana perhatian orang tua terhadap siswa SD Negeri 161/II Bukit Sari Kabupaten Bungo. Untuk mengetahui perhatian orang tua terhadap siswa SD Negeri 161/II Bukit Sari Kabupaten Bungo peneliti menggunakan beberapa indikator perhatian orang tua yaitu dengan melihat dari pemberian bimbingan 
belajar, pengawasan terhadap belajar, pemberian penghargaan dan hukuman, pemenuhan kebutuhan belajar, menciptakan suasana belajar yang tenang dan tentram, memperhatikan kesehatan anak.

Dalam pemberian bimbingan belajar orang tua mengajarkan untuk mengembangkan potensi yang ada dalam diri anak sehingga anak menjadi lebih berkembang dan mencapai hasil belajar yang maksimal. Pemberian bimbingan seperti, membimbing anak ketika ada kesulitan, mendampingi mengerjakan tugas dan memberikan nasehat. Setiap orang tua berkewajiban memberikan bimbingan dan pengajaran yang baik pada anaknya mulai dari cara bersikap bertindak dan berinteraksi dengan orang lain.

Sebagaimana firman Allah SWT:

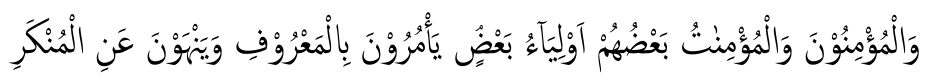

Artinya:

"Dan orang-orang yang beriman, laki-laki dan perempuan, sebagian mereka menjadi penolong bagi sebagian yang lain. Mereka menyuruh (berbuat) yang makruf, dan mencegah dari yang mungkar..." (QS. At-Taubah: 71)

Dari ayat di atas dapat dipahami bahwa orang tua menjadi penolong dalam ketakwaan dan memberikan bimbingan bagi anak-anaknya dengan penuh kasih sayang serta mengajarkan kepada anak untuk berbuat dalam hal kebaikan dan menghindari perbuatan buruk.

Orang tua juga perlu mengawasi pendidikan anak-anaknya karena tanpa adanya pengawasan dari orang tua kemungkinan besar pendidikan anak tidak berjalan lancar. Dengan adanya pengawasan orang tua akan mengetahui kesulitan yang dialami anak dalam belajar dan perkembangan belajarnya. Pengawasan yang dilakukan oleh orang tua berguna untuk membuat anak menjadi lebih disiplin dalam belajar. Pengawasan terhadap anak seperti, mengawasi anak saat belajar di rumah, membatasi jam bermain.

Selain bimbingan dan pengawasan belajar, orang tua perlu memberikan penghargaan yang tujuannya untuk membuat anak lebih semangat dalam belajar, penghargaan dapat berupa pujian ataupun hadiah yang diberikan oleh orang tua untuk anak. Selain dari penghargaan, orang tua hendaknya juga memberikan hukuman apabila melakukan sesuatu yang tidak baik, anak malas dalam belajar. Hukuman yang diberikan tidak boleh melebihi batas, hukuman bertujuan agar anak berhenti melakukan hal yang tidak baik. Pemberian penghargaan seperti, memberikan hadiah ketika anak mendapatkan nilai bagus. Sedangkan pemberian hukuman seperti orang tua memarahi anak ketika bermalas-malasan dalam belajar.

Pemenuhan kebutuhan belajar juga sangat penting bagi anak, karena akan mempermudah anak untuk belajar dengan baik. Kebutuhan belajar adalah segala alat dan sarana untuk menunjang kegiatan belajar anak, seperti alat-alat tulis, seragam sekolah, buku pelajaran, ruang belajar dan lain-lain. Sejalan dengan hal tersebut Walgito (2010) mengatakan bahwa apabila semakin lengkap peralatan belajarnya maka akan semakin baik anak-anak dalam belajar. Sebaliknya, jika alat-alatnya tidak lengkap, maka hal tersebut merupakan gangguan di dalam proses belajar, sehingga hasilnya juga akan mengalami kendala.

Oleh sebab itu, alangkah lebih baik jika orang tua dapat memberikan kebutuhan belajar anak dengan semaksimal mungkin agar memperlancar proses pembelajaran di kelas dan mempermudah dalam belajar di rumah serta meningkatkan semangat belajar anak. Orang tua hendaknya memenuhi kebutuhan belajar anak secukupnya, tidak memberikan secara berlebihan.

Saat anak melaksanakan proses pembelajaran di rumah, orang tua sebaiknya menciptakan suasana rumah yang tenang dan tentram agar anak bisa berkonsentrasi dan tidak terganggu ketika belajar. Peciptaan suasana belajar tenang dan tentram seperti, 
Fidia Rahmawati dan Wirdati: Pengaruh Perhatian Orang Tua terhadap Prestasi Belajar...

orang tua menyediakan ruangan untuk belajar anak, mematikan televisi ketika belajar, menegur orang rumah apabila membuat keributan.

Dan orang tua hendaknya juga harus memperhatikan kondisi kesehatan anak agar proses pembelajaran tidak terganggu akibat tubuh yang tidak sehat. Apabila anak sakit sebaiknya orang tua memeriksakan ke bidan atau puskesmas, memperhatikan makanan anak, melarang anak bermain ketika sedang sakit, memberikan vitamin agar kesehatan tetap terjaga. Jika kesehatan anak baik, maka proses pembelajaran anak juga berjalan dengan baik untuk memperoleh prestasi belajar yang maksimal.

Setelah melakukan analisis data, selanjutnya untuk mengetahui seberapa perhatian orang tua terhadap siswa, penulis melakukan analisis skoring dalam bentuk tabel frekuensi nilai rata-rata perhatian orang tua terhadap siswa SD Negeri 161/II Bukit Sari Kabupaten Bungo sebagai berikut:

Tabel 1. Frekuensi Nilai Rata-rata Perhatian Orang Tua

\begin{tabular}{|c|c|c|c|}
\hline No. & Nilai X & No. & Nilai X \\
\hline 1. & 140 & 23. & 169 \\
\hline 2. & 161 & 24. & 151 \\
\hline 3. & 86 & 25. & 156 \\
\hline 4. & 165 & 26. & 160 \\
\hline 5. & 164 & 27. & 87 \\
\hline 6. & 159 & 28. & 159 \\
\hline 7. & 162 & 29. & 88 \\
\hline 8. & 168 & 30. & 155 \\
\hline 9. & 160 & 31. & 99 \\
\hline 10. & 163 & 32. & 160 \\
\hline 11. & 86 & 33. & 86 \\
\hline 12. & 126 & 34. & 165 \\
\hline 13. & 158 & 35. & 161 \\
\hline 14. & 166 & 36. & 168 \\
\hline 15. & 164 & 37. & 168 \\
\hline 16. & 86 & 38. & 166 \\
\hline 17. & 164 & 39. & 167 \\
\hline 18. & 168 & 40. & 161 \\
\hline 19. & 165 & 41. & 163 \\
\hline 20. & 167 & 42. & 161 \\
\hline 21. & 165 & 43. & 162 \\
\hline \multirow[t]{2}{*}{22.} & 85 & 44. & 85 \\
\hline & & Total & 6425 \\
\hline
\end{tabular}

Berdasarkan data perhatian orang tua terhadap siswa dengan sampel (N) 44 siswa, dengan skor terendah (minimum) 85, skor tertinggi (maksimal) 169, rata-rata (Mean) 146,02, median (Md) 161,00, modus (Mo) sebesar 86, standar deviasi (SD) sebesar 30,939.

Tabel 2. Kategori Perhatian Orang Tua

\begin{tabular}{|c|c|c|c|c|}
\hline $\begin{array}{l}\text { Kategori } \\
\text { Perhatian } \\
\text { Orang Tua }\end{array}$ & $i=28$ & & F & $\%$ \\
\hline Tinggi & $\begin{array}{l}143 \\
171\end{array}$ & - & 33 & $75 \%$ \\
\hline Sedang & 114 & - & 2 & $4,55 \%$ \\
\hline
\end{tabular}




\begin{tabular}{|c|c|l|l|} 
& 142 & & \\
\hline Rendah & $85-113$ & 9 & $20,45 \%$ \\
\hline & Total & 44 & $100 \%$ \\
\hline
\end{tabular}

Berdasarkan tabel di atas terlihat bahwa perhatian orang tua siswa kelas IV dan V di SD Negeri 161/II Bukit Sari Kabupaten Bungo pada interval 85-113 dengan jumlah frekuensi 9 siswa atau sebesar 20,45\% dalam kategori rendah, interval 114-142 dengan jumlah frekuensi 2 siswa atau sebesar 4,55 dalam kategori sedang, interval 143-171 dengan jumlah frekuensi 33 atau sebesar 75\% dalam kategori tinggi. Dari hasil tersebut menunjukkan bahwa perhatian orang tua siswa kelas IV dan V di SD Negeri 161/II Bukit Sari Kabupaten Bungo terdapat pada kategori tinggi.

\section{Gambar 1. Pie Chart Kategori Perhatian Orang Tua}

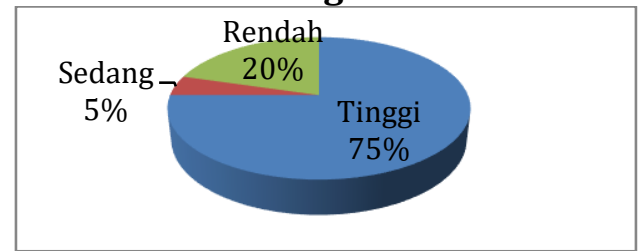

\section{B. Prestasi Belajar Mata Pelajaran Pendidikan Agama Islam Siswa SD Negeri 161/II Bukit Sari Kabupaten Bungo}

Prestasi belajar adalah hasil yang diperoleh siswa dari kegiatan pembelajaran di sekolah bersifat kognitif yang ditentukan melalui penilaian pengetahuan atau keterampilan mata pelajaran yang ditentukan dengan nilai tes yang diberikan oleh guru. Sejalan dengan (Helmawati, 2018) yang menyatakan bahwa prestasi belajar adalah hasil dari pembelajaran, prestasi diperoleh dari penilaian dan setiap anak akan mendapat prestasi belajar yang berbeda-beda. Prestasi yang diperoleh ada yang rendah, sedang dan tinggi. Penulis telah melakukan penelitian dan menguji tentang Pengaruh Perhatian Orang Tua terhadap Prestasi Belajar mata pelajaran Pendidikan Agama Islam Siswa SD Negeri 161/II Bukit Sari Kabupaten Bungo.

Data prestasi belajar mata pelajaran Pendidikan Agama Islam diperoleh dari nilai rapor siswa SD Negeri 161/II Bukit Sari kelas IV dan V pada semester genap tahun pelajaran 2020/2021. Berdasarkan data tersebut, maka prestasi belajar siswa dapat dilihat pada tabel di bawah ini:

Tabel 3. Data Prestasi Belajar Siswa

\begin{tabular}{|l|r|r|r|}
\hline No. & $\begin{array}{l}\text { Nilai } \\
\text { Rapor }\end{array}$ & No. & $\begin{array}{l}\text { Nilai } \\
\text { Rapor }\end{array}$ \\
\hline $\mathbf{1 .}$ & 76 & 23. & 87 \\
\hline $\mathbf{2 .}$ & 80 & 24. & 75 \\
\hline $\mathbf{3 .}$ & 75 & 25. & 76 \\
\hline $\mathbf{4 .}$ & 83 & 26. & 84 \\
\hline $\mathbf{5 .}$ & 89 & 27. & 81 \\
\hline $\mathbf{6 .}$ & 72 & 28. & 72 \\
\hline $\mathbf{7 .}$ & 79 & 29. & 67 \\
\hline $\mathbf{8 .}$ & 89 & 30. & 78 \\
\hline $\mathbf{9 .}$ & 71 & 31. & 69 \\
\hline $\mathbf{1 0 .}$ & 83 & 32. & 82 \\
\hline $\mathbf{1 1 .}$ & 68 & 33. & 79 \\
\hline
\end{tabular}


Fidia Rahmawati dan Wirdati: Pengaruh Perhatian Orang Tua terhadap Prestasi Belajar...

\begin{tabular}{|l|l|l|l|}
\hline $\mathbf{1 2 .}$ & 76 & 34. & 75 \\
\hline $\mathbf{1 3 .}$ & 72 & 35. & 79 \\
\hline $\mathbf{1 4 .}$ & 88 & 36. & 82 \\
\hline $\mathbf{1 5 .}$ & 77 & 37. & 81 \\
\hline $\mathbf{1 6 .}$ & 77 & 38. & 80 \\
\hline $\mathbf{1 7}$ & 78 & 39. & 82 \\
\hline $\mathbf{1 8 .}$ & 84 & 40. & 75 \\
\hline $\mathbf{1 9 .}$ & 71 & 41. & 75 \\
\hline $\mathbf{2 0 .}$ & 74 & 42. & 77 \\
\hline $\mathbf{2 1 .}$ & 75 & 43. & 80 \\
\hline $\mathbf{2 2 .}$ & 80 & 44. & 79 \\
\hline
\end{tabular}

Berdasarkan data prestasi belajar mata pelajaran Pendidikan Agama Islam dari 44 responden diperoleh skor terendah (minimum) sebesar 67 dan skor tertinggi (maxsimum) sebesar 89. Rata-rata (Mean) sebesar 78, Median (Md) sebesar 78, Modus (Mo) sebesar 75, Standar Deviasi (SD) sebesar 5,335.

Tabel 4. Kategori Prestasi Belajar Siswa

\begin{tabular}{|c|c|c|c|}
\hline $\begin{array}{l}\text { Kategori Prestasi } \\
\text { Belajar }\end{array}$ & $i=7$ & F & $\%$ \\
\hline Tinggi & $82-89$ & 11 & $25 \%$ \\
\hline Sedang & $75-81$ & 24 & $54,5 \%$ \\
\hline Rendah & $67-74$ & 9 & $20,5 \%$ \\
\hline
\end{tabular}

Dari variabel prestasi belajar mata pelajaran Pendidikan Agama Islam siswa SD Negeri 161/II Bukit Sari Kabupaten Bungo berada pada interval 67-74 sebanyak 9 siswa atau sebesar 20,5\% termasuk dalam kategori rendah, interval 75-81 sebanyak 24 siswa atau sebesar 54,5\% termasuk dalam kategori sedang, 82-89 sebanyak 11 siswa atau sebesar 25\% termasuk dalam kategori tinggi. Dari hasil tersebut menunjukkan bahwa prestasi belajar mata pelajaran Pendidikan Agama Islam siswa SD Negeri 161/II Bukit Sari terdapat pada kategori sedang.

\section{Gambar 2 \\ Pie Chart Kategori Prestasi Belajar PAI siswa}

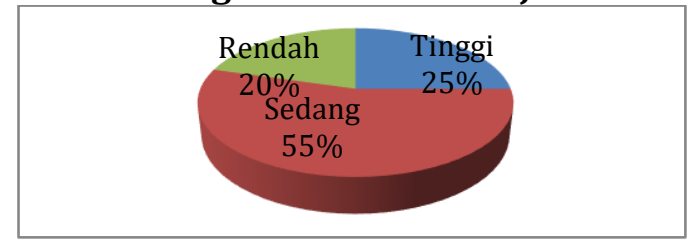

C. Pengaruh Perhatian Orang Tua Terhadap Prestasi Belajar Mata Pelajaran Pendidikan Agama Islam Siswa SD Negeri 161/II Bukit Sari Kabupaten Bungo

Berdasarkan hasil pengujian hipotesis analisis regresi linier sederhana menggunakan program SPSS for Windows versi 24.0. terlihat pada tabel berikut:

\section{Uji Regresi Linier Sederhana \\ Tabel 5. Hasil Uji Regresi Linier Sederhana}




\begin{tabular}{|c|c|c|c|c|c|c|}
\hline \multicolumn{7}{|c|}{ ANOVA $^{b}$} \\
\hline & del & $\begin{array}{l}\text { Sum of } \\
\text { Squares }\end{array}$ & Df & $\begin{array}{l}\text { Mean } \\
\text { Square }\end{array}$ & $\mathbf{F}$ & Sig. \\
\hline 1 & $\begin{array}{l}\text { Regressio } \\
n\end{array}$ & 137.847 & 1 & 137.847 & $\begin{array}{r}5.33 \\
0\end{array}$ & $.026^{a}$ \\
\hline & Residual & 1086.153 & 42 & 25.861 & & \\
\hline & Total & 1.224 .000 & 43 & & & \\
\hline
\end{tabular}

a. Predictors: (Constant), Perhatian Orang Tua

b. Dependent Variable: Prestasi

Belajar

Sumber Data: SPSS for Windows 24.0

Berdasarkan hasil di atas diperoleh $\mathrm{F}_{\text {hitung }}=5,330$. Sedangkan $\mathrm{F}_{\text {tabel }}=4,067$ dengan nilai signifikansi $=0,026<0,05$. Adapun kriteria $\mathrm{H}_{\mathrm{o}}$ ditolak jika $\mathrm{F}_{\text {hitung }}>\mathrm{F}_{\text {tabel }}$ dengan $\alpha$ $=0,05(5 \%)$ dengan nilai 5,330 > 4,067. Maka hasil uji regresi linier sederhana ini dapat diartikan bahwa $\mathrm{H}_{\mathrm{a}}$ menyatakan perhatian orang tua berpengaruh positif terhadap prestasi belajar siswa diterima, dan $\mathrm{H}_{0}$ ditolak.

Tabel 6.

\begin{tabular}{|c|c|c|c|c|c|c|}
\hline \multicolumn{7}{|c|}{ Coefficients $^{\mathrm{a}}$} \\
\hline & \multirow[t]{2}{*}{ Model } & \multicolumn{2}{|c|}{$\begin{array}{l}\text { Unstandardized } \\
\text { Coefficients }\end{array}$} & \multirow{2}{*}{$\begin{array}{c}\text { Standardized } \\
\text { Coefficients } \\
\text { Beta }\end{array}$} & \multirow[t]{2}{*}{$T$} & \multirow[t]{2}{*}{ Sig. } \\
\hline & & B & $\begin{array}{l}\text { Std. } \\
\text { Error }\end{array}$ & & & \\
\hline \multirow[t]{2}{*}{1} & $\begin{array}{l}\text { (Constan } \\
\text { t) }\end{array}$ & $\begin{array}{r}69.55 \\
0\end{array}$ & 3.740 & & $\begin{array}{r}18.59 \\
8\end{array}$ & .00 \\
\hline & $\begin{array}{l}\text { Perhatian } \\
\text { Orang } \\
\text { Tua }\end{array}$ & .058 & .025 & .336 & 2.309 & .02 \\
\hline Pre & $\begin{array}{l}\text { endent Var } \\
\text { si Belajar }\end{array}$ & & & & & \\
\hline
\end{tabular}

Sumber Data: SPSS for Windows 24.0

Berdasarkan tabel di atas, maka persamaan regresi sederhana dapat dinyatakan sebagai berikut:

Ket:

$$
\mathrm{Y}=\alpha+\mathrm{bX}
$$

$\mathrm{Y}=$ Prestasi Belajar

$\mathrm{X}=$ Perhatian Orang Tua

Diperoleh koefisien X sebesar 0,058 dan konstanta sebesar 69,550 Maka dapat digambarkan bentuk hubungan variabel perhatian orang tua terhadap prestasi belajar dalam bentuk persamaan regresi:

$$
\mathrm{Y}=69,550+0,058 \mathrm{X}
$$

Variabel perhatian orang tua $(X)$ sebesar 0,058 menunjukkan bahwa jika variabel perhatian orang tua $(\mathrm{X})$ meningkat 1 satuan maka akan meningkatkan prestasi belajar sebesar 0,058 satuan atau sebesar $5,8 \%$.

\section{Uji T}

Pengujian hipotesis secara parsial yang dimaksudkan untuk mengetahui ada atau tidaknya pengaruh variabel independen $(\mathrm{X})$ secara parsial terhadap variabel dependen $(\mathrm{Y})$. 
Fidia Rahmawati dan Wirdati: Pengaruh Perhatian Orang Tua terhadap Prestasi Belajar...

$\mathrm{H}_{\mathrm{a}}=$ Terdapat pengaruh yang signifikan antara perhatian orang tua terhadap prestasi belajar siswa

$\mathrm{H}_{\mathrm{o}}=$ Tidak terdapat pengaruh yang signifikan antara perhatian orang tua terhadap prestasi belajar siswa.

Pengambilan keputusan ditentukan dengan cara sebagai berikut:

a) Jika nilai Sig $<\alpha(0,05)$ atau $t_{\text {hitung }}>$ dari $t_{\text {tabel }}$ maka $\mathrm{H}_{\mathrm{a}}$ diterima dan $\mathrm{H}_{\mathrm{o}}$ ditolak

b) Jika nilai Sig $>\alpha(0,05)$ atau $t_{\text {hitung }}<$ dari $t_{\text {tabel }}$ maka $\mathrm{H}_{\mathrm{o}}$ diterima dan $\mathrm{H}_{\mathrm{a}}$ ditolak

c)

Tabel 7.

Hasil Uji T

\begin{tabular}{|c|c|c|c|c|c|c|}
\hline \multicolumn{7}{|c|}{ Coefficientsa } \\
\hline \multicolumn{2}{|c|}{ Model } & \multicolumn{2}{|c|}{$\begin{array}{l}\text { Unstandardized } \\
\text { Coefficients }\end{array}$} & \multirow{2}{*}{$\begin{array}{c}\text { Standardized } \\
\text { Coefficients } \\
\text { Beta }\end{array}$} & \multirow[t]{2}{*}{$\mathrm{T}$} & \multirow[t]{2}{*}{ Sig. } \\
\hline & & B & $\begin{array}{l}\text { Std. } \\
\text { Error }\end{array}$ & & & \\
\hline 1 & $\begin{array}{l}\text { (Constan } \\
\text { t) }\end{array}$ & $\begin{array}{r}69.55 \\
0\end{array}$ & 3.740 & & $\begin{array}{r}18.59 \\
8\end{array}$ & .000 \\
\hline & $\begin{array}{l}\text { Perhatian } \\
\text { Orang } \\
\text { Tua }\end{array}$ & .058 & .025 & .336 & 2.309 & .026 \\
\hline & $\begin{array}{l}\text { ndent Va } \\
\text { i Belajar }\end{array}$ & & & & & \\
\hline
\end{tabular}

Sumber Data: SPSS for Windows 24.0

Untuk mengetahui apakah signifikan atau tidak, dengan menggunakan perbandingan $t_{\text {hitung }}$ dan tabel dengan taraf signifikan 0,05 dan $\mathrm{N}=44$, dengan derajat kebebasan (df) $=\mathrm{n}-\mathrm{k}-1=44-1-1=42$ (n adalah jumlah responden dan $\mathrm{k}$ adalah jumlah variabel independen), maka hasil yang diperoleh dari $t_{\text {tabel }}$ adalah 1,682.

Berdasarkan tabel di atas, cara membandingkan hasil dari $t_{\text {hitung }}$ dengan $t_{\text {tabel }}$ adalah dari tabel Coefficients ${ }^{\mathrm{a}}$ di atas diperoleh nilai $\mathrm{t}_{\text {hitung }}=2,309$ dan untuk $\mathrm{t}_{\text {tabel }}=$ 1,682. Maka perbandingan dari keduanya adalah $t_{\text {hitung }}>t_{\text {tabel }}(2,309>1,682)$. Nilai signifikansi t untuk variabel perhatian orang tua $(X)$ adalah 0,026 dan nilai tersebut lebih kecil daripada probabilitas $0,05(0,026<0,05)$. Jadi, dalam pengujian ini menunjukkan bahwa $\mathrm{H}_{\mathrm{a}}$ diterima dan $\mathrm{H}_{\mathrm{o}}$ ditolak. Hal ini berarti terdapat pengaruh yang signifikan antara perhatian orang tua terhadap prestasi belajar mata pelajaran pendidikan agama islam siswa SD Negeri 161/II Bukit Sari Kabupaten Bungo.

\section{Koefisien Determinasi}

Koefisien determinasi $\left(\mathrm{R}^{2}\right)$ digunakan untuk mengetahui seberapa besar sumbangan variabel independen (perhatian orang tua) terhadap variabel dependen (prestasi belajar). Berikut hasil output uji koefisien determinasi $\mathrm{R}^{2}$ :

Tabel 8.

Hasil Koefisien Determinasi 


\begin{tabular}{|c|c|c|c|c|c|c|c|c|c|}
\hline \multicolumn{10}{|c|}{ Model Summaryb } \\
\hline \multirow[b]{2}{*}{ Model } & \multirow[b]{2}{*}{$\mathrm{R}$} & \multirow[b]{2}{*}{$\begin{array}{c}\mathrm{R} \\
\text { Squar } \\
\mathrm{e}\end{array}$} & \multirow[b]{2}{*}{$\begin{array}{l}\text { Adjuste } \\
\text { d R } \\
\text { Square }\end{array}$} & \multirow[b]{2}{*}{$\begin{array}{l}\text { Std. } \\
\text { Error of } \\
\text { the } \\
\text { Estimat } \\
\mathrm{e}\end{array}$} & \multicolumn{5}{|c|}{ Change Statistics } \\
\hline & & & & & $\begin{array}{c}\mathrm{R} \\
\text { Squar } \\
\mathrm{e} \\
\text { Chang } \\
\mathrm{e} \\
\end{array}$ & $\begin{array}{c}\mathrm{F} \\
\text { Chang } \\
\mathrm{e}\end{array}$ & df1 & df2 & $\begin{array}{c}\text { Sig. F } \\
\text { Chang } \\
\text { e }\end{array}$ \\
\hline 1 & $.336^{\mathrm{a}}$ & .113 & .091 & 5.085 & .113 & 5.330 & 1 & 42 & .026 \\
\hline \multicolumn{10}{|c|}{$\begin{array}{l}\text { a. Predictors: (Constant), Perhatian } \\
\text { Orang Tua }\end{array}$} \\
\hline \multicolumn{10}{|c|}{ b. Dependent Variable: Prestasi Belajar } \\
\hline
\end{tabular}

Sumber Data: SPSS for Windows 24.0

Dari hasil output diketahui nilai R square adalah 0,113 (11,3\%), menunjukkan bahwa dengan menggunakan model regresi variabel independen yaitu perhatian orang tua memiliki pengaruh terhadap variabel dependen yaitu prestasi belajar siswa. Sedangkan sisanya $88,7 \%$ disebabkan oleh faktor atau variabel lain yang tidak diketahui dan tidak termasuk dalam analisis regresi ini.

Berdasarkan hasil uji hipotesis perhatian orang tua terhadap prestasi belajar mata pelajaran Pendidikan Agama Islam menunjukkan bahwa $t_{\text {hitung }}$ sebesar 2,309 dan $t_{\text {tabel }}$ sebesar 1,682 dengan taraf signifikansi sebesar 0,05 . Nilai signifikansi untuk perhatian orang tua adalah 0,026 dan nilai tersebut lebih kecil dari pada nilai probabilitas 0,05 $(0,026<0,05)$. Oleh sebab itu dalam pengujian ini $t_{h i t u n g}>t_{\text {tabel }}$ dan disimpulkan bahwa $\mathrm{H}_{a}$ = diterima dan $\mathrm{H}_{\mathrm{o}}=$ ditolak hal ini berarti terdapat pengaruh yang signifikan antara perhatian orang tua terhadap prestasi belajar siswa. Hasil dari pengujian hipotesis perhatian orang tua terhadap prestasi belajar diketahui bahwa pengaruhnya sebesar $11,3 \%$ sedangkan $88,7 \%$ dipengaruhi oleh faktor lain yang tidak diteliti dalam penelitian ini.

Prestasi belajar siswa dipengaruhi oleh banyak faktor, baik dari dalam dan luar diri siswa. Faktor dari dalam diri siswa yaitu faktor fisiologis dan faktor psikologis yang meliputi minat, tingkat intelegensi, motivasi, bakat dan minat siswa. Sedangkan salah satu faktor dari luar yang mempengaruhi prestasi belajar siswa adalah keluarga dalam hal ini perhatian orang tua. Berdasarkan pendapat (Purnamawati, 2011) menyatakan bahwa perhatian orang tua memiliki pengaruh yang signifikan terhadap prestasi belajar siswa. Perhatian orang tua harus diberikan secara cukup dan tepat, karena jika anak kekurangan perhatian dari orang tua maka prestasi belajar akan rendah, tetapi jika orang tua terlalu banyak memberikan perhatian kepada anaknya akan menimbulkan sikap manja yang akan menyebabkan kemalasan dalam belajar dan prestasi belajar rendah. Sejalan dengan hal tersebut (Slameto, 2010) berpendapat bahwa siswa yang belajar akan mendapat pengaruh dari keluarga seperti cara orang tua dalam mendidik anak dengan memberi perhatian terhadap pendidikan anak, memenuhi kebutuhan anak dalam belajar, mengawasi anak saat belajar di rumah, membantu kesulitan anak serta menciptakan suasana rumah yang nyaman dan tentram.

\section{Simpulan}

Berdasarkan hasil penelitian yang telah dipaparkan di atas tentang pengaruh perhatian orang tua terhadap prestasi belajar mata pelajaran Pendidikan Agama Islam siswa SD Negeri 161/II Bukit Sari maka dapat disimpulkan: Pertama, Perhatian orang tua siswa SD 161/II Bukit Sari Kabupaten Bungo Tahun Pelajaran 2020/2021 tergolong dalam kategori tinggi. Hal ini ditunjukkan dengan interval 143-171 dengan jumlah 33 siswa atau sebesar 75\%. Kedua, 
Fidia Rahmawati dan Wirdati: Pengaruh Perhatian Orang Tua terhadap Prestasi Belajar...

Prestasi belajar siswa SD Negeri 161/II Bukit Sari Kabupaten Bungo Tahun Pelajaran 2020/2021 tergolong dalam kategori sedang. Hal ini ditunjukkan pada interval 75-81 sebanyak 24 siswa atau sebesar $54,5 \%$. Ketiga, Terdapat pengaruh yang signifikan antara perhatian orang tua terhadap prestasi belajar mata pelajaran Pendidikan Agama Islam siswa SD Negeri 161/II Bukit Sari . Hal ini dapat dilihat dari hasil analisis Uji T diperoleh $t_{\text {hitung }}>t_{\text {tabel }}$ $(2,309>1,682)$ menunjukkan $\mathrm{H}_{\mathrm{o}}$ ditolak dan Ha diterima. Dan hasil perhitungan dari analisis regresi linier sederhana diperoleh nilai $\mathrm{F}_{\text {hitung }}=5,330$ dan $\mathrm{F}_{\text {tabel }}=4,067$ dengan nilai signifikansi $0,026<0,05$. Jadi $F_{\text {hitung }}>F_{\text {tabel }}(5,330>4,067)$ sehingga dapat diartikan bahwa $\mathrm{H}_{\mathrm{o}}$ ditolak dan terdapat pengaruh yang signifikan antara perhatian orang tua terhadap prestasi belajar siswa. Dari koefisien determinasi nilai R square adalah 0,113 (11,3\%), menunjukkan bahwa dengan menggunakan model regresi variabel independen yaitu perhatian orang tua memiliki pengaruh terhadap variabel dependen yaitu prestasi belajar siswa. Sedangkan sisanya $88,7 \%$ disebabkan oleh faktor atau variabel lain yang tidak diketahui dan tidak termasuk dalam analisis regresi ini.

\section{Referensi}

Ahmadi, A. (2009). Psikologi Umum. Jakarta: PT. Rineka Cipta.

Daradjat, Z. (2011). Ilmu Pendidikan Islam. Jakarta: PT. Bumi Aksara.

Djaelani, M. S. (2013). Peran Pendidikan Agama Islam Dalam Keluarga Dan Masyarakat. Jurnal Ilmiah WIDYA, Vol 1 (2).

Hamdu, G., \& Agustina, L. (2011). Pengaruh Motivasi Belajar Siswa Terhadap Prestasi Belajar IPA Di Sekolah Dasar. Jurnal Penelitian Pendidikan, Vol 12 (1).

Hasibuan, Ricky Anasari. (2019). Pengaruh Perhatian Orang Tua Terhadap Prestasi Belajar Siswa Di MTs Al-Aminatul Hidiriyah Desa Pangirkiran Kecamatan Halongonan Kabupaten Padang Lawas Utara. Skripsi. Institut Agama Islam Negeri PadangSidimpuan

Helmawati. (2018). Mendidik Anak Berprestasi Melalui 10 Kecerdasan. Bandung: PT Remaja Rosdakarya.

Latief, Abdul. (2014). Pengaruh Lingkungan Sekolah Terhadap Hasil Belajar Pendidikan Kewarganegaraan Pada Peserta Didik Di SMK Negeri Paku Kecamatan Binuang Kabupaten Polewali Mandar. Jurnal Pepatuzdu, Vol 7 (1).

Lie, A., Andriono, T., \& Sarah, P. (2014). Menjadi Sekolah Terbaik: Praktik-Praktik Strategis Dalam Pendidikan. Jakarta: Tanoto Foundation dan Raih Asa Sukses.

Mawarsih, S. E., Susilaningsih, \& Hamidi, N. (2013). Pengaruh Perhatian Orang Tua Dan Motivasi Belajar Terhadap Prestasi Belajar Siswa SMA Negeri Jumapolo. JUPE UNS, 1(3), $1-13$.

Ningsih, R., \& Nurrahmah, A. (2016). Pengaruh Kemandirian Belajar Dan Perhatian Orang Tua Terhadap Prestasi Belajar Matematika. Jurnal Formatif, 6 (1).

Nisa, A. (2015). Pengaruh Perhatian Orang Tua Dan Minat Belajar Siswa Terhadap Prestasi Belajar Ilmu Pengetahuan Sosial. Jurnal Ilmiah Pendidikan, II(1), 1-9.

Pratiwi, N. K. (2015). Pengaruh Tingkat Pendidikan, Perhatian Orang Tua, Dan Minat Belajar Siswa Terhadap Prestasi Belajar Bahasa Indonesia Siswa SMK Kesehatan Di Kota Tangerang. Jurnal Pujangga, 1(2), 31. https://doi.org/10.47313/pujangga.v1i2.320

Purnamawati, Ika Ratna. (2011). Hubungan Perhatian Orang Tua dan Motivasi Belajar terhadap Prestasi Belajar Siswa Kelas X Jurusan Administrasi Perkantoran SMK Batik 2 Surakarta Tahun Diklat 2010/2011. Skripsi: Surakarta.

Qomariyah, S. N. (2015). Pengaruh Perhatian Orang Tua Terhadap Prestasi Belajar Menjahit Pada Siswa SMPN 2 Mojogedeng Kabupaten Karanganyar. Jurnal Keluarga, 1(1), 55-61.

Ristianah, N. (2015). Pendidikan Anak Dalam Keluarga. Jurnal Studi Pendidikan dan Hukum Islam, Vol 1 (2).

Sandrawati F, Indira. (2016). Pengaruh Lingkungan Sosial Siswa Dan Kondisi Ekonomi Orangtua Terhadap Prestasi Belajar Siswa Di SMP Negeri 9 Kota Probolinggo. Jurnal Penelitian dan Pendidikan IPS (JPPI), Vol 10 (2).

Slameto. (2010). Belajar dan Faktor-Faktor Yang Mempengaruhinya. Jakarta: PT. Rineka 
Cipta.

Suryabrata, S. (2015). Psikologi Pendidikan. Jakarta: PT. Raja Grafindo Persada.

Syah, M. (2012). Psikologi Belajar. Jakarta: Rajawali Press.

Syah, M. (2013). Psikologi Belajar. Jakarta: Rajawali Press.

Umar, M. (2015). Peranan Orang Tua Dalam Peningkatan Prestasi Belajar Anak. JURNAL EDUKASI: Jurnal Bimbingan Konseling, 1(1), 20. https://doi.org/10.22373/je.v1i1.315

Wahab, R. (2016). Psikologi Belajar. Jakarta: PT. Raja Grafindo Persada.

Walgito, Bimo. (2010). Pengantar Psikologi Umum. Yogyakarta: CV Andi

Zindiari, Riffat Khasinah. (2020). Pengaruh Perhatian Orang Tua Terhadap Prestasi Belajar Pendidikan Agama Islam Siswa Kelas IV SD Negeri 35 Kota Bengkulu. Skripsi. Bengkulu: Institut Agama Islam Negeri Bengkulu 